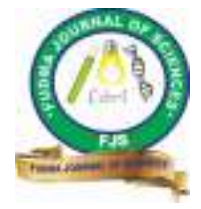

FUDMA Journal of Sciences (FJS)

ISSN online: $2616-1370$

ISSN print: 2645 - 2944

Vol. 4 No. 3, September, 2020, pp $247-251$

DOI: https://doi.org/10.33003/fjs-2020-0403-388

\title{
IN-VIVO ANTI-DIARRHOEAL ACTIVITY AND PHYTOCHEMICAL SCREENING OF ETHANOL STEM BARK EXTRACT OF VITELLARIA PARADOXA GAERTN F. (SAPOTACEAE)
}

\author{
*Abdullahi Z, Jimoh A. A., Patrick B. E, Yakubu M. I and Mallam D.
}

Department of Pharmacology and Toxicology, Faculty of Pharmaceutical Sciences, Kaduna State University, Kaduna-Nigeria

*Corresponding Author's email: zulaihatua@yahoo.com, Tel: +234(080)33111317

\begin{abstract}
Different parts of Vitellaria paradoxa plant have many applications in ethno-medicine. Some of the uses of this plant include treatment of diarrhoea and other GIT disorders. In this study the antidiarrhoeal activity of the ethanol extract of Vitellaria paradoxa was evaluated using three experimental models: Castor oil-induced diarrhoea; small intestinal motility and intestinal fluid accumulation (enteropooling) models in mice. Five groups of five mice were used for each model. Group one mice received $10 \mathrm{ml} / \mathrm{kg}$ of distilled water, while groups 2, 3, and 4 received 125,250 and $500 \mathrm{mg} / \mathrm{kg}$ of the extract orally respectively. Group 5 mice received Loperamide $5 \mathrm{mg} / \mathrm{kg}$ orally. Oral median lethal dose $\left(\mathrm{LD}_{50}\right)$ of the extract was determined using OECD (2008) Guideline 425. Phytochemical studies were conducted using standard procedures. The LD $\mathrm{D}_{50}$ was estimated to be greater than $5000 \mathrm{mg} / \mathrm{kg}$ body weight and there were no signs of mortality or visible signs of toxicity in all the mice treated. Phytochemical screening revealed the presence of carbohydrates, alkaloids, flavonoids, saponins, tannins, triterpenes, steroids, cardiac glycosides and anthraquinones glycosides. Extract showed a dose-dependent anti-diarrhoeal activity by reducing stool frequency and consistency. The extract at the higher doses significantly $(\mathrm{p}<0.05)$ inhibited GIT motility and castor oil-induced enteropooling, comparable to that of the reference control drug Loperamide. The study showed that ethanol stem bark extract of Vitellaria paradoxa possess anti-diarrhoeal activity and thus justifies its ethno-medicinal use in the treatment of diarrhoea.
\end{abstract}

Keywords: Anti-diarrhoeal, Castor oil, Enteropooling, Loperamide, Phytochemical..

\section{INTRODUCTION}

Diarrhoea, the passage of liquid faeces, is a major problem in children under five years of age in developing countries. Diarrhoea is a leading killer of children and it accounts for about $9 \%$ of all deaths among children under age of five worldwide (UNICEF, 2016). Some Saharan Africa and Southern Asia were the regions with the highest child death rate due to diarrhoea in 2015 (Liu et al., 2016). The World Health Organization (WHO) estimated that about $80 \%$ of the world population, presently use some herbal medicine for some aspect of their primary healthcare (Matu and Van-Staden, 2003).

In developing countries where poverty is wide spread, coupled with poor sanitation and lack of safe drinking water, the incidence of diarrhoea is high among the populace. Accessibility and high cost of modern medicine for the treatment of diarrhoea, have made herbal medicines cheaper and more readily available alternatives in many rural communities. Examples of herbal medicines used in treatment of diarrhoea include: Acacia niloca, Acanthospermum hispidum, Parkia biglobosa, Vitex doniana, Gmelina arborea (Agunu et al., 2005); Zehneria scabra, Calpurnia aurea, Coffea arabica, Cordi aafricana and Indigofera spicata (Woldeab et al., 2018).

The plant is a small to medium sized tree $(7-25 \mathrm{~m})$ that is found naturally in the wild dry Savannah belt of West Africa (Senegal, Benin, Ghana, Nigeria and Cameroon). Common names are: Shea-butter tree (English), Kadanya (Hausa), Emiemi (Yoruba), Kareje (Fulani) and Okwuma (Igbo). Ethnomedicinal uses include: Diarrhoea, dysentery, helminthic and other G.I.T infections, skin diseases and wound infections (Soladoye et al., 1989), cough and leprosy (Ferry et al., 1974) and in the cosmetic industry.

This study was conducted to validate the traditional use of Vitellaria paradoxa in the treatment of diarrhoeal diseases.

\section{MATERIALS AND METHODS}

\section{Plant collection and identification}

The stem bark of Vitellaria paradoxa was collected in June 2019 in Zaria, Zaria Local Government Area of Kaduna State. It was identified and authenticated by Mallam Shehu Umar Gallah, a Taxonomist in the Department of Biological Sciences, Kaduna State University, Kaduna. Specimen voucher number 900072 was assigned and deposited at the Herbarium in Department of Biological Sciences, Kaduna State University, Kaduna for future reference.

\section{Plant preparation and extraction}

The stem barks collected were air-dried under shade, size reduced using mortar and pestle. It was then grinded to fine powdered using a mechanical grinder (Binatone). $250 \mathrm{~g}$ of the powdered plant material was macerated in $2.5 \mathrm{~L}$ of $96 \%$ ethanol at room temperature for 72 hours with occasional stirring. The liquid was then strained off and the solid residue (marc) was pressed to remove the solution as much as possible. Filtration was carried out using clean muslin cloth and then with Whatman number one filter paper. The extract was 
concentrated in a Rotary evaporator (Searchtech Instrument RE 52-3) and finally dried in an oven for 5 days at temperature of $50^{\circ} \mathrm{C}$ under reduced pressure. The dried extract was weighed, then kept at $4^{\circ} \mathrm{C}$ in a refrigerator in an amber air-tight container until required for use. The percentage yield was calculated as:

Weight of extracted material $\quad$ × 100

Weight of starting plant material

\section{Experimental animals}

Healthy adult Swiss Albino male and female mice (16-28 g) obtained from Animal House, Department of Pharmacology and Toxicology, Kaduna State University, Kaduna, were randomized and used for the study. All animals were kept in clean dry cages maintained in a well-ventilated animal house at a controlled temperature $\left(25 \pm 1{ }^{\circ} \mathrm{C}\right)$ and a 12-hour dark/light cycle. Animals had free access to water and food ad libitum. All experiments were conducted according to the principles and NIH (2011) guidelines for the use and care of Laboratory animals.

\section{Phytochemical screening}

Phytochemical screening of extract was carried out using the methods described by Trease and Evans (2004) and Sofowora (2008). Extract was screened for the presence or absence of alkaloids, flavonoids, saponins, tannins, glycosides, steroids, triterpenes, anthraquinones and carbohydrates.

\section{Oral acute toxicity study}

The acute toxicity test was carried out using the OECD (2008) guideline 425 up and down method. Three adult Swiss albino mice (19-21 g) were used for the study. The dose used for the limit test was $5000 \mathrm{mg} / \mathrm{kg}$. The test was carried out using the oral route of administration. One mouse was starved of food but not water for 3 hours, after which it was administered the extract at a dose of $5000 \mathrm{mg} / \mathrm{kg}$ of body weight orally. Food was withheld for another one hour. It was observed for signs and symptoms of toxicity (sedation, sniffing, grooming and rearing) and mortality for 24 hours. Two additional mice were then dosed at the same limit test dose of $5000 \mathrm{mg} / / \mathrm{kg}$ body weight orally. They were observed for signs of toxicity and mortality for 24 hours. All tested mice were observed for 14 days without further dosing with the extract.

\section{Anti-Diarrhoeal Studies}

Castor oil-induced diarrhoea model

The modified method described by Atta and Mouneir (2004) was used for the study. Twenty-five mice were randomly divided into five groups of five mice each and were fasted overnight before the experiment. Group 1 mice (negative control) received $10 \mathrm{ml} / \mathrm{kg}$ of distilled water, while Groups 2, 3 and 4 received 125,250 and $500 \mathrm{mg} / \mathrm{kg}$ of ethanol extract of Vitellaria paradoxa orally respectively. Group 5 mice (positive control) received Loperamide $5 \mathrm{mg} / \mathrm{kg}$ orally. All mice were administered $0.3 \mathrm{ml}$ of Castor oil orally 30 minutes after treatment and were kept in individual cages with the floor lined with white blotting papers. The number of both normal and watery stools passed were counted every hour for 4 hours. Mean number of stools passed by the treated groups was compared with those of the controls. The $\%$ of wet faeces was calculated as follows:

Mean number of wet faeces $\times 100$
Total number of faeces

\section{Effect on small intestinal motility}

The method of Vogel et al., 2002 was used. Twenty-five mice were weighed and randomly divided into five groups of five mice each. Mice were fasted overnight before the experiment commenced. Group 1 mice (negative control) received 10 $\mathrm{ml} / \mathrm{kg}$ of distilled water orally, while Groups 2, 3 and 4 received 125,250 and $500 \mathrm{mg} / \mathrm{kg}$ body weight of extract orally respectively. Group 5 mice (positive control) received Loperamide $5 \mathrm{mg} / \mathrm{kg}$ body weight orally. Standard charcoal meal was administered to all the animals one hour after treatment. Thirty minutes after charcoal administration, the animals were anaesthetized by using light Halothane and then sacrificed. The intestines were immediately removed and ligated at the pyloric splinter and ileocecal junction. The small intestine transit was measured as \% of distance travelled by the charcoal meal compared to the total length of the small intestine from the pyloric splinter to the ileocecal junction.

\section{Effect of extract on enteropooling}

The method of Hassan et al., 2011 was used. Twenty-five mice were weighed and randomly divided into five groups of five mice each. The mice were fasted overnight before the experiment. Group 1 mice (negative control) received $10 \mathrm{ml} / \mathrm{kg}$ body weight of distilled water orally, while Groups 2, 3 and 4 received 125,250 and $500 \mathrm{mg} / \mathrm{kg}$ body weight of extract orally respectively. Group 5 mice (positive control) received Loperamide $5 \mathrm{mg} / \mathrm{kg}$ body weight orally. One hour after treatment, mice were sacrificed under Halothane anaesthesia and the intestines removed and weighed. The content of each intestine was milked out, and the empty intestines were reweighed. The difference in weight between the full and empty intestines were recorded as the weight of the intestinal content.

\section{STATISTICAL ANALYSIS}

All quantitative data were presented as the mean \pm standard error of mean (SEM) and were analysed using one-way ANOVA, followed by Bonferroni Post Hoc multiple comparison's tests. Differences were assessed at 95\% level of significance and $p$-values $\leq 0.05$ were considered significant.

\section{RESULTS AND DISCUSSION}

The extract obtained was light brown in colour and the percentage yield was $3.8 \%$. The oral administration of Vitellaria paradoxa was well tolerated, even at the highest dose, as no death or clinical signs of toxicity were observed throughout the fourteen days observation period. In the first phase of the study, the mouse that was dosed at $5000 \mathrm{mg} / \mathrm{kg}$ body weight survived after 24 hours observation period. The two mice dosed at $5000 \mathrm{mg} / \mathrm{kg}$ body weight in the second phase also survived after 24 hours observation period. The limit test was terminated and the oral median lethal dose (LD 50$)$ of the extract, which was estimated to be greater than 5000 $\mathrm{mg} / \mathrm{kg}$ body weight, suggests that the plant extract was nontoxic.

The extract was found to contain the following constituents: Carbohydrate, Flavonoids, Alkaloids, Tannins, Saponins, Cardiac glycosides and Steroids/Triterpenes. However, there was no Anthraquinones.

Results of phytochemical screening were similar to those 
obtained by El-Mahmood et al., 2008 and Ndukwe et al., 2007. Phenolic compounds (flavonoids and tannins), glycoside moieties (saponins, anthracene and cardiac glycosides) are known to protect against gastric infections (El-Mahmood et al., 2008). Flavonoids, when present, are also claimed to inhibit the release of autacoids and prostaglandins, thereby inhibiting motility and secretion induced by castor oil, and to inhibit contraction caused by spasmogenes (Dharmalingam et al., 2014).
The extract produced significant $(p<0.05)$ dose-dependent decrease in the mean number of wet faeces compared to the negative control (distilled water). The extract at doses of 250 and $500 \mathrm{mg} / \mathrm{kg}$ body weight caused $89.3 \%$ inhibition of wet faeces as compared to $75 \%$ inhibition produced by Loperamide $5 \mathrm{mg} / \mathrm{kg}$ body weight. But these inhibitions of wet faeces were not significantly $(\mathrm{p}>0.05)$ different (Table 1$)$.

All the doses of the extract tested and Loperamide $5 \mathrm{mg} / \mathrm{kg}$ body weight produced a significantly $(\mathrm{p}<0.05)$ lower loss in body weight as compared to the negative control (Table 2 ).

Table 1: Effect of Vitellaria paradoxa stem bark extract against Castor oil-induced diarrhoea

\begin{tabular}{lcc}
\hline TREATMENT & MEAN NUMBER OF WET FAECES & \% INHIBITION \\
\hline Distilled water $(10 \mathrm{ml} / \mathrm{kg})$ & $5.6 \pm 2.38$ & 35.7 \\
VPSE $(125 \mathrm{mg} / \mathrm{kg})$ & $3.6 \pm 1.47^{*}$ & 89.3 \\
VPSE $(250 \mathrm{mg} / \mathrm{kg})$ & $0.6 \pm 0.60^{*}$ & 89.3 \\
VPSE $(500 \mathrm{mg} / \mathrm{kg})$ & $0.6 \pm 0.24^{*}$ & 75.0 \\
Loperamide $(5 \mathrm{mg} / \mathrm{kg})$ & $1.4 \pm 0.51^{*}$ & \\
\hline
\end{tabular}

Values are mean \pm SEM, $\mathrm{n}=5$, One-way ANOVA + Bonferroni post hoc test, $* \mathrm{p} \leq 0.05=$ significant difference between treatment groups and negative control. D/W = Distilled water; VPSE = Vitellara paradoxa stem bark extract (125, 250 and 500 $\mathrm{mg} / \mathrm{kg}$ body weight);

Table 2: Effect of Vitellaria paradoxa stem bark extract on body weight of mice in Castor oil-induced diarrhoea

\begin{tabular}{|c|c|c|c|c|}
\hline TREATMENT & $\begin{array}{l}\text { MEAN } \\
\text { BEFORE (g) }\end{array}$ & $\begin{array}{l}\text { MEAN WEIGHT } \\
\text { AFTER (g) }\end{array}$ & \begin{tabular}{l}
\multicolumn{2}{l}{ DIFFERENC } \\
E IN \\
WEIGHT (g)
\end{tabular} & $\begin{array}{l}\% \\
\text { DIFFERENCE }\end{array}$ \\
\hline $\mathrm{D} / \mathrm{W}(10 \mathrm{ml} / \mathrm{kg})$ & $25.0 \pm 0.55$ & $21.8 \pm 1.22$ & 3.2 & 12.8 \\
\hline VPSE $(125 \mathrm{mg} / \mathrm{kg})$ & $22.0 \pm 0.71$ & $21.1 \pm 0.55$ & 0.9 & 4.1 \\
\hline VPSE $(250 \mathrm{mg} / \mathrm{kg})$ & $22.8 \pm 1.28$ & $21.4 \pm 1.12$ & 1.4 & 6.1 \\
\hline VPSE (500 mg/kg) & $23.02 \pm 0.92$ & $21.4 \pm 0.70$ & 1.5 & 6.6 \\
\hline Loperamide ( $5 \mathrm{mg} / \mathrm{kg}$ ) & $21.8 \pm 0.37$ & $20.5 \pm 0.34$ & 1.3 & 6.0 \\
\hline
\end{tabular}

Values are mean \pm SEM, $n=5$, One-way ANOVA, $\mathrm{p}>0.05=$ no significant difference between treatment groups and negative control. $\mathrm{D} / \mathrm{W}=$ Distilled water; VPSE = Vitellaria paradoxa stem bark extract (125, $250 \mathrm{and} 500 \mathrm{mg} / \mathrm{kg}$ body weight)

intestinal transit (Sharkey and Wallace, 2011; Sadraei et al.,

Diarrhoea occurs due to imbalance in the absorptive and secretory mechanism in the intestinal tract which involves motility and secretory functions (Eke and Anaga, 2013). Castor oil-induced diarrhoea, small intestinal motility and intestinal fluid accumulation (enteropooling) are standard models for screening anti-diarrhoeal agents. The extract at the doses used successfully inhibited the castor oil-induced diarrhoea. The anti-diarrhoea activity might have been exerted via an antisecretory mechanism, which was seen from the decrease in total number of wet faeces and reduction of intestinal fluid accumulation in the treated groups. Castor oil is a triglyceride of Ricinoleic acid and its hydrolysis in the small intestine liberates the Ricinoleic acid, which primarily acts on the small intestine to stimulate secretion of fluid, electrolyte and speed 2011). Studies have shown that the diarrhoeal effects of Castor oil are due to the induction of contraction of intestinal smooth muscles mediated by the activation of E prostanoid 3 receptors on intestinal smooth muscles (Al-Fartosy, 2013; Tunaru et al., 2012).

There was a dose-dependent decrease in percentage movement of charcoal in the extract treated groups. However, these reductions in percentage movement of charcoal were not statistically significant $(p>0.05)$ when compared with that of the negative control (Table 3$)$. Loperamide significantly $(\mathrm{p}<$ $0.05)$ reduced the percentage movement of charcoal $(57.3 \%)$ when compared with negative control (Table 3 ). 
Table 3: Effect of Vitellaria paradoxa stem bark extract on small intestinal motility

\begin{tabular}{lcc}
\hline TREATMENT & DISTANCE TRAVELLED BY CHARCOAL MEAL (CM) & \% MOVEMENT OF \\
CHARCOAL (CM) & & 85.3 \\
\hline Distilled water $(10 \mathrm{ml} / \mathrm{kg})$ & $38.4 \pm 1.12$ & 74.9 \\
VPSE $(125 \mathrm{mg} / \mathrm{kg})$ & $36.0 \pm 1.59$ & 70.6 \\
VPSE $(250 \mathrm{mg} / \mathrm{kg})$ & $32.8 \pm 1.75$ & 60.7 \\
VPSE $(500 \mathrm{mg} / \mathrm{kg})$ & $29.8 \pm 3.49$ & 57.3 \\
Loperamide $(5 \mathrm{mg} / \mathrm{kg})$ & $27.3 \pm 2.58^{*}$ &
\end{tabular}

Values are mean \pm SEM, $n=5$, One-way ANOVA + Bonferroni post hoc test, ${ }^{*} \mathrm{p} \leq 0.05=$ significant difference between treatment groups and negative control. D/W = Distilled water; VPSE = Vitellaria paradoxa stem bark extract $(125,250$ and 500 $\mathrm{mg} / \mathrm{kg}$ body weight);

Table 4: Effect of Vitellaria paradoxa stem bark extract on weight of small intestinal fluid

\begin{tabular}{lcc}
\hline TREATMENT & WEIGHT OF INTESTINAL FLUID $(\mathbf{g})$ & \% INHIBITION \\
\hline Distilled water $(10 \mathrm{ml} / \mathrm{kg})$ & $1.06 \pm 0.06$ & 20.8 \\
VPSE $(125 \mathrm{mg} / \mathrm{kg})$ & $0.84 \pm 0.16$ & 49.1 \\
VPSE $(250 \mathrm{mg} / \mathrm{kg})$ & $0.54 \pm 0.11^{*}$ & 57.5 \\
VPSE $(500 \mathrm{mg} / \mathrm{kg})$ & $0.45 \pm 0.06^{*}$ & 67.0 \\
Loperamide $(5 \mathrm{mg} / \mathrm{kg})$ & $0.35 \pm 0.03^{*}$ & \\
\hline
\end{tabular}

Values are mean \pm SEM, $n=5$, One-way ANOVA + Bonferroni post hoc test, $* \mathrm{p} \leq 0.05=$ significant difference between treatment groups and negative control. D/W = Distilled water; VPSE = Vitellaria paradoxa stem bark extract (125, 250 and 500 $\mathrm{mg} / \mathrm{kg}$ body weight);

The extract doses at $250,500 \mathrm{mg} / \mathrm{kg}$ and Loperamide at 5 $\mathrm{mg} / \mathrm{kg}$ body weight statistically and dose-dependently reduced $(\mathrm{p} \leq 0.05)$ intestinal fluid accumulation when compared with the negative control. The standard drug, Loperamide also produced statistically significant reduction in weight of intestinal fluid $(\mathrm{p} \leq 0.05)$ as compared with the negative control. However, there were no significant differences between values for Loperamide and the extract groups (Table 4).

Another possible mechanism for the anti-diarrhoeal activity of Vitellaria paradoxa may be due to the inhibition of lipase and nitric oxide synthase activities. Agents that act through these mechanisms may prevent the laxative effects of Castor oil (AlFartosy, 2013).

The anti-motility effect of Vitellaria paradoxa may also be via antagonistic activity of muscarinic receptors and agonist action on intestinal $\alpha-2$ adenoceptors (Salako et al., 2015). Loperamide, the standard drug used, slows down intestinal motility by affecting the circular and longitudinal muscles of the intestine, through interaction with the $\mu$-opioid receptors there (Mazumdar et al., 2015; Tzeng et al., 2005; Tanko et al., 2012).

\section{CONCLUSION}

The results obtained in the study suggest that the stem bark extract of Vitellaria paradoxa possess anti-diarrhoeal activity in chemical-induced diarrhoeal models that justifies its use in ethno-medicinal treatment of diarrhoea. Further studies should be carried out to identify the active constituent and the mechanism of action of the anti-diarrhoeal activity.

\section{Conflict of interest statement}

The authors declare that they have no conflict of interest.

\section{ACKNOWLEDGEMENTS}

The authors are grateful to Mallam Umar Gallah of the Department of Biological Sciences for plant collection and identification; and to $\mathrm{Mr}$ Bitrus Achi of Department of Pharmacology and Toxicology for his assistance in execution of this work.

\section{REFERENCES}

Agunu, A., Yusuf, S., Andrew, G.O., Zezi, A.U., Abdurahman, E.M. (2005). Evaluation of five medicinal plants used in diarrhea treatment in Nigeria. Journal of Ethnopharmacology. 101(1-3); 27-30. Dio: 10. 1016/j.jep.2005.03025.

Al-Fartosy, A.J.M. (2013). Some Pharmacological studies on the methanol extract of Inula graveolense L. Journal of Biomedical Science Eng. 6: 1040-9.

Atta, A.H., Mouneir, S.M. (2004). Anti-diarrhoeal activity of some Egyptian medicinal plant extracts. Journal of Ethnopharmacology. 92(2-3): 303-9.

Bizaneh, W., Reta, R., Tibebu, A and Mea, M. (2018). Medicinal plants for treatment of diarrhoeal related diseases in Ethiopia. Review Article/Open Access. Vol. 2018/Article ID 4630371/20 pages. http://doi.org/10.1155/2018/4630371.

Sharkey, K.A and Wallace, J.L. (2011). Treatment of Disorders of Bowel Motility and Water Flux: Antiemetics, Agents used in Biliary and Pancreatic Diseases. In: Goodman and Gilman's The Pharmacological Basis of Therapeutics, 12 ${ }^{\text {th }}$ Edition, Brunton, L.L., Chabner, B.A., Knollmann, B. C. (Ed) New York. McGraw-Hill Medical. P1336-1339.

Dharmalingam, S.R., Madhappan, R., Ramamurthy, S., Chidambaram, K., Srikanth, M.V., Shanmugham, S and Senthil Kumar, K.L. (2014). Investigation on ant-idiarrhoeal activity of Aristolochia indica Linn root extracts in mice. African Journal of Traditional Complementary Alternative Medicine. 11(2): 292-294.

Eke, I.G, and Anaga, A.O. (2013). Anti-diarrhoeic properties of the aqueous methanol extract of Palisota hirsute leaves and its 
fractions in mice. International Journal of Recent Science Res. 4(4): $410-4$

El-Mahmood, A.M., Doughari, J.H., Ladan, N. (2008). Antimicrobial screening of stem bark extract of Vitellaria paradoxa against some enteric pathogenic microorganisms. African Journal of Pharmacy and Pharmacology. 2(5), 089094.

Evans, W.C. (2009). Trease and Evans 'Pharmacognosy' $16^{\text {th }}$ Edition; Edinburgh: Saunders Ltd.

Ferry, M.P., Gessain, M and Gessain, R. (1987). Vegetative propagation of Shea, Kola and Pentadesma. Cocoa Research Institute Ghana Ann. Rep 1987/88: 98-100

Hasan, K.A., Brenda, A.T., Patrick, O.E. (2011). In-vivo antidiarrhoeal activity of the ethanol leaf extract of Catharanthus roseus Linn (Apocyanaceae) in Wistar rats. African Journal of Pharmacy and Pharmacology. 5(15): 1797-800

Liu, L., Oza, S., Hogan, D. (2016). Global regional and national cases of under-five mortality in 2000-2015: An updated systematic analysis with implications for the Sustainable Development Goals. The Lancet. Vol. 388, no. 10063, pp 3027-3035. View at: Publisher site/Google Scholar.

Matu, E.N and Van-Staden, J. (2003). Anti-diarrhoeal and antiinflammatory activities of some plants used for medicinal purposes in Kenya. Journal of Ethnopharmacology 87, 35-41

Mazumdar, S., Akter, R., Talukder, D. (2015). Antidiabetic and anti-diarrhoeal effects on ethanol extracts of Psidium guajava (L) Bat. Leaves in Wistar rats. Asian Pacific Journal of Tropical Biomed; 5(1): 10-4.

Ndukwe, I.G., Amupitan, Y., Isah, Y and Adegoke, K.S. (2007). Phytochemical and antimicrobial screening of the crude extracts from the root, stem bark and leaves of Vitellaria paradoxa. African Journal of Biotechnology; 6: 1905-1909.

Organization for Economic Cooperation and Development (OECD). 2008 Guidelines for the testing of chemicals, acute oral toxicity- up and down procedure No. 425. Paris: Organization for Economic Cooperation and Development.
Sadraei, H., Asghari, G and Shams, M. (2011). Anti-diarrhoeal action of Hydroalcoholic extract of Pycnocyclaspinose in comparison with Loperamide and Dicyclomine. Iran J. Pharm Res. 10(4): 835-4.

Sofowora, A. (2008). Medicinal plants and traditional medicine in Africa. Third edition Spectrum Books Ltd Ibadan, Nigeria. 199-202.

Soladoye, M.O., Orhere, S.S., Ibimode, B.M. (1989). Ethnobotanical study of two indigenous multipurpose plants in the Guinea Savanna of Kwara State - Vitellaria paradoxa and Parkia biglobosa. Biennial Conference of Ecological Society of Nigeria. August 1989. Forestry Research Institute, Ibadan, 1989: 13.

Solako, O.A., Akindele, A.J., Shitta, O.M., Elegunde, O.O and Adeyemi, O.O. (2015). Anti-diarrhoeal activity of aqueous leaf extract of Caladium bicolor (Araceae) and its possible mechanism of action. Journal of Ethnopharmacology; Dec 24, 176: $225-31$.

Tanko, Y, Alladey, O, Ahmed, M.K., Mohammed, A., Musa, K.Y. (2012). The effect of methanol leaves extract of Ficus glumosa on gastrointestinal motility and on Castor oil-induced diarrhoea in Laboratory animals. Journal of Natural Product Plant Resource. 2(3): 360-7.

Tunaru S, Althoff TF; Nusing RM; Diener M and Offermanns S. (2012). Castor oil induces laxation and uterus contraction via ricinoleic acid activating prostaglandin EP3 receptors. Proc. National Academy of Science U.S.A. 109(23) 9179-84.

Tzeng, T.F., Liu, I.M., Cheng, J.T. (2005). Activation of Opiod $\mu$-receptors by Loperamide to improve interleukin-6-induced inhibition of insulin signals in myoblast $\mathrm{C} 2 \mathrm{C} 12$ cells. Diabetologia. 48(7):1386-92.

United Nations International Children Education Fund (UNICEF). (2016). 'One is too many': Ending child death from pneumonia and diarrhoea. http: //www.unicef.org/publications/index-93020.html

Vogel, H.G., Vogel, W.H., Scholkens, B.A., Sandow, J., Muller, G., Vogel, W.F. (2002). Drug discovery and evaluation: Pharmaceutical assays. $2^{\text {nd }}$ ed. Berlin; Springer-Verlag. 